\title{
Compounds that inhibit triglyceride accumulation and TNF $\alpha$ secretion in adipocytes
}

\author{
Naofumi Shiomi, Miwako Maeda, Minori Mimura
}

School of Human Sciences, Kobe College, Nishinomiya, Japan.

Email: n-shiomi@mail.kobe-c.ac.jp

Received 19 September 2011; revised 17 October 2011; accepted 30 October 2011.

\begin{abstract}
Obese subjects show both a fatty predisposition and a higher risk of metabolic syndrome. This characteristic depends on adipocytes. However, the roles of adipocytes in metabolic syndrome have been insufficiently investigated, because few pure adipocyte cell lines have been isolated. The present study had two objectives: the isolation of a pure adipocyte cell line and clarification of the differences between adipocytes and preadipocytes, and screening for compounds that can potentially prevent metabolic syndrome. We isolated a novel adipocyte cell line, 3T3L24. In the 3T3-L24 cells, the gene expression levels (of C/EBP $\alpha$ and $\beta$, PPAR $\gamma$ and AP2) and the production of triglyceride and TNF $\alpha$ were much higher than those in the preadipocyte 3T3-L1 cells. We used the 3T3-L24 adipocytes to screen for compounds that could inhibit triglyceride accumulation and TNF $\alpha$ secretion. Fatty acids enhanced the triglyceride accumulation. Sodium carboxylate, taurine and carnitine not only inhibited triglyceride accumulation, but also inhibited TNF $\alpha$ secretion. Therefore, these compounds might be effective to decrease the risk of metabolic syndrome in obese subjects.
\end{abstract}

Keywords: Adipocyte; Metabolic Syndrome; Triglyceride; TNF $\alpha$; Fatty Acid; Carboxylate; Taurine; Carnitine

\section{INTRODUCTION}

Obesity has been gradually increasing in Japan because of the changes in eating habits, shortage of exercise and increase in work-related stress [1]. The risk for hyperglycemia, diabetes, and heart disease in obese people is approximately 2 - 4 times higher than that in normalweight persons. This trio of effects is well known as "metabolic syndrome". According to research performed by the Ministry of Health, Labor and Welfare of Japan in 2006, half of males and one-fifth of females among those over 40 years old show signs of metabolic syndrome, making the prevention (and treatment) of metabolic syndrome an important subject in Japan.

The mechanism responsible for metabolic syndrome has been studied since the 1990s. White adipose tissue (WAT) works as an endocrine organ, and provides energy storage by the accumulation of triglycerides [2]. WAT secretes many adipocytokines [3-7], such as adiponectin, leptin and tumor necrosis factor alpha $(\mathrm{TNF} \alpha)$, which can induce insulin resistance and decrease glucose control, which are among the first symptoms of metabolic syndrome. For example, a standard-weight person generally has $5-10 \mu \mathrm{g} / \mathrm{ml}$ of adiponectin in the blood, but the concentration in patients with type 2 diabetes or ischemic heart disease is much lower [8]. The administration of adiponectin to these patients was effective for reducing their symptoms. Leptin, a neuropeptide, works as an inhibitor of appetite [6]. The administration of leptin to diabetic patients led to recovery from insulin resistance [9]. TNF $\alpha$ induces the expression of migration inhibitory factor (MIF), which is also related to insulin resistance [10]. Consequently, insulin resistance and the unusual metabolism of glucose associated with metabolic syndrome are caused by the induction of TNF $\alpha$ and the repression of leptin and adiponectin in the WAT.

Recent studies have also suggested that hypertrophy of the WAT is an important factor in metabolic syndrome. Hypertrophy of the WAT causes not only the aging of adipocytes, but also inflammation by the obliteration of the blood flow. This inflammation facilitates the gathering of macrophage and secretion of adipocytokines from the disrupted cells of the WAT [11]. In experiments using rats, an increase in the expression of $\mathrm{p} 53$ and secretion of proinflammatory factors was found in hypertrophic WAT [12].

The ratio of adipocytes to preadipocytes is very high in obese in comparison with normal-weight people. Therefore, to avoid the development of metabolic syndrome in obese subjects, it is important to fully under- 
stand the characteristics of adipocytes. However, no pure adipocyte cell line has been isolated, and therefore, the characteristics of adipocytes have not yet been fully elucidated. In this study, we isolated a novel adipocyte cell line, which we confirmed based on its characteristics of triglyceride accumulation and $\mathrm{TNF} \alpha$ secretion. We then used this cell line to screen for potential inhibitors of these functions. Our results may be useful for the preventing the development of metabolic syndrome in obese subjects.

\section{MATERIALS AND METHODS}

\subsection{Cell Line and Culture Condition}

The mouse preadipocyte line, 3T3-L1, which was originnally generated from the Swiss albino mouse fibroblast cell line, 3T3, by Green [13] was obtained from Dainippon Sumitomo Pharma Corporation (Osaka, Japan). Dulbecco's modified Eagle's medium (DMEM) containing sodium bicarbonate (MP Biomedicals Inc., IIIkirch, France) and fetal bovine serum (FBS), which was treated at $56^{\circ} \mathrm{C}$ for $30 \mathrm{~min}$, were mixed at a ratio $9: 1$, and the mixture (DMEM medium containing 10\% FBS) was used as a basic culture medium. The cells were cultured in a $\mathrm{CO}_{2}$ incubator at $37^{\circ} \mathrm{C}$.

\subsection{Isolation of Adipocytes}

The following differentiation procedure was carried out to obtain pure adipocytes based on a revision of a method described in a previous study [14]. The 3T3-L1 preadipocytes $\left(2.0 \times 10^{5}\right.$ cells $)$ were cultured in $15 \mathrm{ml}$ of DMEM medium containing 10\% FBS for 2 days in 75 $\mathrm{cm}^{2}$ flasks, then the medium was replaced with DMEM containing $10 \% \mathrm{FBS}, 0.5 \mu \mathrm{M}$ of 3-iisobutyl-1-methylxanthine (IBMX) and $4 \mu \mathrm{M}$ of dexamethasone. The cells were cultured for 2 additional days to differentiate 3T3L1 cells into adipocytes. The medium was replaced again with DMEM containing $10 \% \mathrm{FBS}$ and $10 \mu \mathrm{g} / \mathrm{mL}$ of human insulin, and the cells were cultured for 2 additional days to mature the cells.

After three repeated differentiation steps to enrich the ratio of adipocytes to preadipocytes, the cells were suspended and diluted in DMEM containing 10\% FBS. The diluted cells were cultured to construct single colonies in $8 \mathrm{ml}$ medium in $10 \mathrm{~cm}^{2}$ plates for 7 days. A stainless cup ( $1 \mathrm{~cm}^{2}$ diameter) was used to covered each colony, then the cells were removed from the culture using $0.1 \mu \mathrm{l}$ of $0.25 \%$ trypsin, collected in a $1.5 \mathrm{ml}$ microtube, and washed with a DMEM medium containing 10\% FBS. The cells collected from each colony were cultured in 5 $\mathrm{ml}$ of medium in $2.5 \mathrm{~cm}^{2}$ plates for 7 days. Finally, a cell line which contained more oil drops in comparison with the preadipocyte $3 \mathrm{~T} 3-\mathrm{L} 1$ line was isolated as a novel adipocyte cell line, and was named 3T3-L24.

\subsection{The Production of Triglycerides and TNF $\alpha$ in Preadipocytes and the Newly-Isolated Adipocytes}

The amounts of triglyceride and TNF $\alpha$ produced by the preadipocytes and adipocytes were examined. The preadipocyte 3T3-L1 cell line and the adipocyte 3T3-L24 cell line $\left(5 \times 10^{5}\right.$ cells $)$ were cultured in two $75 \mathrm{~cm}^{2}$ flasks containing $15 \mathrm{ml}$ of DMEM medium for one day, and $0.28 \mathrm{mM}$ oleic acid was added to one of the flasks. After another 3 days of culture, the culture broth was removed for the analysis. The triglyceride level in the cells was found to have gradually increased during the cultivation, and the culture conditions (the lot number of cells, pre-culture conditions, number of inoculated cells and culture time) also led to differences in the triglyceride level (data not shown). Thus, we elected to determine the triglyceride content when $90 \%$ - 95\% of the glucose in the medium was consumed. To measure the concentration, the cells were washed once with PBS solution containing $0.02 \mathrm{mM}$ of EDTA, detached with $0.25 \%$ trypsin solution, and harvested. The concentrations of protein, triglycerides and $\mathrm{TNF} \alpha$ in cells were assayed using the cells. A total of 3 - 4 independent experiments were performed, and the average values, standard error (S.E.) and p-value (by the $t$-test) were calculated.

\subsection{The Effects of Additives on the Triglyceride and TNF $\alpha$ Production in Adipocytes}

The 3T3-L24 adipocytes $\left(5 \times 10^{5}\right.$ cells $)$, which were pre-cultured in $8 \mathrm{ml}$ of DMEM containing $10 \% \mathrm{FBS}$, were cultured in several $75 \mathrm{~cm}^{2}$ flasks for one day, and then were exposed to $20 \mathrm{mM}$ glycerol, $0.28 \mathrm{mM}$ longchain fatty acids (steric, oleic and linoleic acids), 0.5 $\mathrm{mM}$ of carboxylates (sodium acetate, sodium citrate, sodium malate and sodium oleate), $0.5 \mathrm{mM}$ of carnitine, $0.5 \mathrm{mM}$ of taurine). The effective concentration of the additive was determined by preliminary experiments (data not shown). After another 3 days of culture (90\% $100 \%$ of the glucose was consumed), the culture broth was removed, the cells were washed with $0.02 \mathrm{mM}$ of EDTA/PBS solution, detached with $0.25 \%$ trypsin solution, and harvested. The concentration of protein and triglyceride in the cells and the concentration of TNF $\alpha$ in the medium were analyzed. Three independent experiments were performed, and the average, S.E. and p-values (by $t$-test) were calculated.

\subsection{Assays}

The triglyceride concentration in the cells was analyzed by the following method developed in our laboratory: 
the cells cultured in a $75 \mathrm{~cm}^{2}$ flask were collected in a $1.5 \mathrm{ml}$ of microtube. The cell pellet was suspended in $100 \mu 1$ of phosphate buffered saline (PBS) and disrupted by using an ultrasonic disrupter (TOMY SEIKO Co. Ltd., Tokyo, Japan) for $30 \mathrm{~s}$ under a strength of 8 . Then, $5 \mu \mathrm{l}$ of the solution was used for the analysis of total protein, and the rest of the volume was used for the analysis of the triglyceride concentration. Diethyl ether $(400 \mu 1)$ was mixed with the rest of the solution and centrifuged at $14,000 \times \mathrm{g}$ for $10 \mathrm{~min}$. The upper layer (diethyl ether containing oil) was transferred to a new $1.5 \mathrm{ml}$ of microtube, and the diethyl ether was allowed to evaporate at room temperature for $12 \mathrm{~h}$. The oil drop that remained after drying was dissolved in $10 \mu \mathrm{l}$ isopropanol, and the total amount of triglyceride was measured by the Triglyceride E Test Wako kit (Wako Chem. Co. Ltd., Osaka, Japan). Using this method, the glycerol and lipids initially contained in the cells were removed during the extraction operation, and they did not affect the measurement of the triglyceride. The total triglyceride level could be measured to a concentration as low as 0.01 $\mathrm{mg} / \mathrm{ml}$.

The concentrations of TNF $\alpha$ were analyzed as follows: the cells cultured in $75 \mathrm{~cm}^{2}$ flasks were collected in 1.5 $\mathrm{ml}$ microtubes, and the cell pellets were suspended in $200 \mu 1$ of PBS and disrupted by using an ultrasonic disrupter. Next, $5 \mu 1$ of the solution was used for the analysis of total protein, and the rest was used for the analysis of TNF $\alpha$. The amounts of TNF $\alpha$ present in the cells and culture medium were determined using a highly sensitive ELISA [15].

The concentration of total protein was determined by a protein assay kit (Bio-Rad Laboratories, Inc., Tokyo, Japan). The static error in cell number counted with a cell counter was much higher than that of the total amount of protein present in adipocytes. Therefore, we utilized the value based on the total amount of protein instead of the cell number for comparison.

\subsection{Expression of mRNAs}

The 3T3-L1 preadipocytes and the 3T3-L24 adipocytes $\left(5 \times 10^{5}\right.$ cells $)$ were cultured in $8 \mathrm{ml}$ of DMEM containing $10 \% \mathrm{FBS}$ in $25 \mathrm{~cm}^{2}$ flasks for 4 days. The preadipocytes were also cultured in DMEM containing 10\% FBS and $4 \mu \mathrm{M}$ dexamethasone and $0.5 \mu \mathrm{M}$ 3-iisobutyl-1methyl xanthine (IBMX), and $10 \mu \mathrm{g} / \mathrm{mL}$ of human insulin for 4 days. We named the differentiated cells 3T3-L2, and the expression of genes in the 3T3-L1, 3T3-L2 and 3T3-L24 cell lines was compared by real-time PCR.

The total mRNA in the cells was purified, and the cDNAs were synthesized by using an RNeasy Lipid Tissue Mini kit and a QuantiTeck Reverse Transcription kit. The reaction mixture for real-time PCR was pre- pared with the Rotor-Gene SYBR Green PCR Kit. QuanTech Primer Assays [Mm Aclb 2 SG (QT01136772), Mm_Fabp4_1_SG (QT00091532), Mm_Cebpa_1_SG (QT00311731), Mm Cebpb 1 SG (QT00320313), Mm Ppag_1_SG (QT00100296)] were used as the primers for $\beta$-actin, AP2, CCAAT/enhancer binding protein $(\mathrm{C} / \mathrm{EBP}) \alpha, \mathrm{C} / \mathrm{EBP} \beta$, and PPAR $\gamma$. These kits and primers were obtained from Qiagen K. K. (Tokyo, Japan). Realtime PCR was performed by the using Rotor-Gene ${ }^{\mathrm{TM}}$ device (Qiagen K. K.). The reaction was performed for 70 cycles of treatment at $95^{\circ} \mathrm{C}$ for $5 \mathrm{~s}$ and $65^{\circ} \mathrm{C}$ for $10 \mathrm{~s}$. The threshold line and $\mathrm{Ct}$ values were determined by using the Rotor-Gene 6000 series software program, and the relative amount of mRNA in 3T3-L24 adipocytes or the differentiated 3T3-L2 cells in comparison with that in preadipocyte 3T3-L1 (control) was determined by the $\Delta \Delta \mathrm{Ct}$ method, followed by calculating the $\Delta \mathrm{Ct}$ values by using $\beta$-actin as a house-keeping gene. Three independent experiments were performed, and the average values, S.E. and p-vales were calculated.

\section{RESULTS}

\subsection{A Novel Adipocyte Cell Line, and Its Expression of Signaling Genes}

We tried to isolate a novel adipocyte cell line because a suitable adipocyte line had not yet been isolated from 3T3-L1 preadipocytes. As shown in the Materials and Methods section, dexamethasone, IBMX and insulin were used to induce the differentiation of the mouse preadipocytes into adipocytes. Following three round of differentiation to enrich the ratio of adipocytes, colonies were formed on the dishes. A cell line which contained more oil drops in comparison with the 3T3-L1 preadipocytes was finally isolated as a novel adipocyte cell line, and was named 3T3-L24 (Figure 1(a)).

Increased expression of the $\mathrm{AP} 2, \mathrm{C} / \mathrm{EBP} \alpha, \mathrm{C} / \mathrm{EBP} \beta$ and PPAR $\gamma$ genes are known to indicate the differentiation to adipocytes [16-19]. Thus, we compared the expression levels of these genes in the 3T3-L24 cells with those in the parental 3T3-L1 cells or in the differentiated

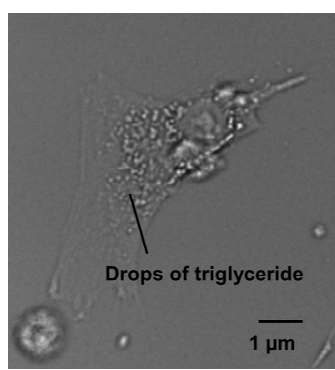

(a)

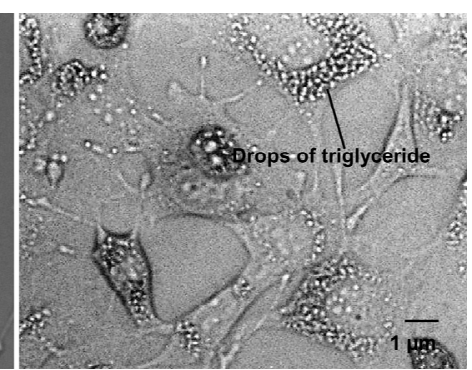

(b)
Figure 1. Photographs of the 3T3-L24 adipocytes cultured without (a) and with $0.28 \mathrm{mM}$ oleic acid (b). 
3T3-L2 cells by using a real-time PCR method. The 3T3-L1 and 3T3-L24 cells were cultured in DMEM containing $10 \% \mathrm{FBS}$, and the differentiated $3 \mathrm{~T} 3-\mathrm{L} 2$ cells were cultured in the same basic medium containing dexamethasone, IBMX and insulin. Figure 2 shows the ratios of mRNA expression in the 3T3-L24 adipocytes or the differentiated 3T3-L2 cells to those of 3T3-L1 preadipocytes. As shown in Figure 2(a), the expression of the AP2 and $\mathrm{C} / \mathrm{EBP} \beta$ genes in the 3T3-L2 cells were 1.5 times higher than those in the 3T3-L1 cells, but the expression levels of $\mathrm{C} / \mathrm{EBP} \alpha$ and $\operatorname{PPAR} \gamma$ were lower. These results suggest that the differentiation in the 3T3-L2 cells was not complete. However, in the 3T3L24 adipocytes, the gene expression levels of AP2, $\mathrm{C} / \mathrm{EBP} \alpha, \mathrm{C} / \mathrm{EBP} \beta$ and $\mathrm{PPAR} \gamma$ were $8.8,23.2,1.6$ and 5.0 times higher than those in the 3T3-L1 cells $(\mathrm{p}<0.01)$, even though the 3T3-L24 cells were cultured without the addition of dexamethasone, IBMX and insulin.

\subsection{The Production of Triglycerides and TNF $\alpha$ by the 3T3-L24 and 3T3-L1 Cells}

We compared the amount of triglyceride present in 3T3-L24 adipocytes with that in 3T3-L1 preadipocytes. Figure 3(a) shows the amount of triglyceride present in cells cultured for $72 \mathrm{hr}$ in the DMEM containing 10\% FBS. These average values in 3T3-L24 and 3T3-L1 cells were 0.087 and $0.031 \mathrm{mg}$ triglyceride/mg protein, respectively. The production of TNF $\alpha$ was also compared. Figure 3(b) shows the amount of TNF $\alpha$ in the cells cultured under the same conditions as in Figure 3(a). The average value of TNF $\alpha$ contained in the 3T3-L24 cells was $0.68 \mathrm{ng} / \mathrm{mg}$ protein, but the value in the $3 \mathrm{~T} 3-\mathrm{L} 1$ cells was only $0.007 \mathrm{ng} / \mathrm{mg}$ protein (the value of TNF $\alpha$ in the medium was not detectable).

\subsection{Compounds That Increase the Triglyceride Level in the 3T3-L24 Adipocytes}

Triglyceride is synthesized from glycerol and long-chain fatty acids. Thus, we investigated the effects of the addition of glycerol and long-chain fatty acids on the triglyceride accumulation in the 3T3-L24 cells. Figure 3 shows the amount of triglyceride present in the cells cultured in DMEM containing 10\% FBS with the addition of glycerol or long-chain fatty acids. A small increase in triglyceride accumulation was found when 22 $\mathrm{mM}$ of glycerol was added. On the other hand, many oil droplets (Figure 1(b)) appeared when the cells were cultured with $0.28 \mathrm{mM}$ of long-chain fatty acids. The average values of triglyceride in cultures with the addition of oleic acid and linolenic acid were 0.51 and 0.29 $\mathrm{mg} / \mathrm{mg}$ protein, respectively (Figure 3(a)). These values

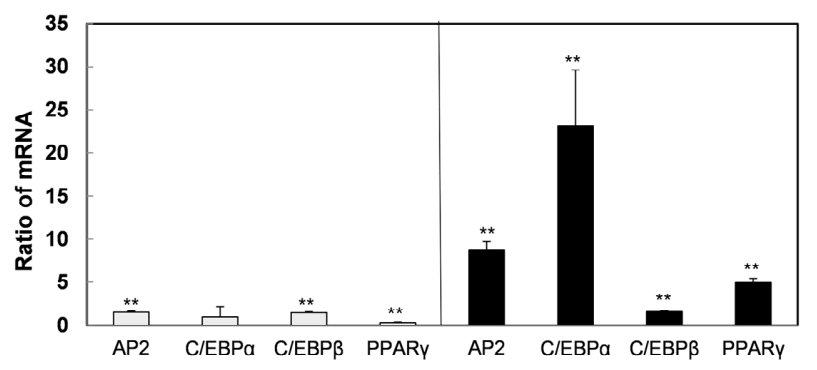

(a)

(b)

Figure 2. The ratio of the mRNA expression in the 3T3-L2 differentiated cells (a) or 3T3-L24 adipocytes (b) per 3T3-L1 preadipocyte. The 3T3-L1 and 3T3-L24 cells were cultured in DMEM containing $10 \%$ FBS (the basic medium) for 4 days, and the 3T3-L2 cells were cultured in the basic medium containing $4 \mu \mathrm{M}$ dexamethasone, $0.5 \mu \mathrm{M}$ IBMX, and $10 \mu \mathrm{g} / \mathrm{mL}$ of human insulin. Bars, means \pm S.E. of three independent experiments. ${ }^{*} \mathrm{p}<0.05$ vs. control (3T3-L1), ${ }^{* *} \mathrm{p}<0.01$.

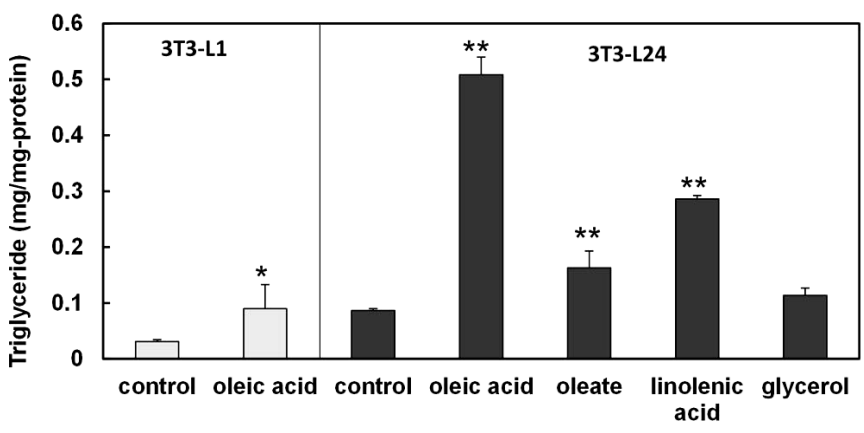

(a)

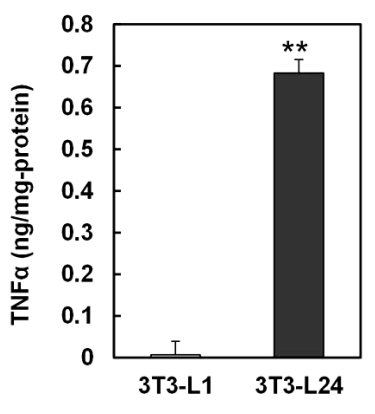

(b)

Figure 3. The amounts of triglyceride (a) and TNF $\alpha$ (b) present in the 3T3-L1 preadipocytes and 3T3-L24 adipocytes. The 3T3-L1 cells were cultured in the basic media without any additional factors (control) or with $0.28 \mathrm{mM}$ of oleic acid. The 3T3-L24 cells were cultured in the basic media without additional factors (control) or with $0.28 \mathrm{mM}$ of oleic acid, sodium oleate, or linolenic acid and $22 \mathrm{mM}$ of glycerol. The 3T3-L1 and 3T3-L24 cells were cultured without additional factors to examine the amount of TNF $\alpha$ present in the cells. Bars, means \pm S.E. of the 3 independent experiments. ${ }^{*} \mathrm{p}<0.05$ vs. control (without addition) and ${ }^{* *} \mathrm{p}<0.01$. 
were much higher than the value without the addition of either of these factors $(0.086 \mathrm{mg} / \mathrm{mg}$ protein). Further, the amount of triglyceride accumulation in cells subjected to culture media with the addition of sodium oleate was only $32 \%$ in comparison with the addition of oleic acid. Even in the 3T3-L1 preadipocytes, the amount of triglyceride was also enhanced from 0.031 to 0.090 $\mathrm{mg} / \mathrm{mg}$ protein by the addition of $0.28 \mathrm{mM}$ oleic acid (Figure 3(a)), but the value was much lower than that in the 3T3-L24 adipocytes $(0.51 \mathrm{mg}$ triglyceride/mg protein).

\subsection{Compounds That Inhibit Triglyceride and TNF $\alpha$ Production in Adipocytes}

We examined whether the triglyceride accumulation could be inhibited by using sodium acetate, citrate, carnitine and taurine. As shown in Figure 4(a), the average triglyceride present in cells treated with the addition of sodium acetate, citrate, carnitine and taurine were decreased to $57 \%, 39 \%, 79 \%$ and $26 \%$ in comparison of the cells treated without these factors (control) (all $\mathrm{p}<0.01$ ). Additionally, the cells were treated with these agents in combination with sodium oleate, which was used as a representative free fatty acid, and the effects of these compounds were examined again. As shown in Figure 4(b), the average triglyceride present in the cells treated with sodium citrate, carnitine and taurine were decreased to $44 \%, 33 \%$, and $46 \%$ (all $p<0.01$ ) of the control value, even in the presence of sodium oleate. Therefore, the additions of these compounds were effective to inhibit the triglyceride accumulation.

The effects of triglyceride accumulation on TNF $\alpha$ secretion were also examined. Figure 5 shows the amount of TNF $\alpha$ present in the medium of cells cultured under the same conditions (except acetate) as in Figure 4. The concentration of TNF $\alpha$ in cells cultured with sodium oleate was decreased to $68 \%$ in comparison with those without (control). Moreover, when sodium citrate, carnitine and taurine were added, the TNF $\alpha$ secretion was decreased to $90 \%, 38 \%$ and $43 \%$ in cells cultured without sodium oleate and $67 \%, 9.4 \%$ and $33 \%$ in cases where cells were also cultured with sodium oleate. Of interest, the values after treatment with carnitine and taurine were significantly different from the control $(\mathrm{p}<$ 0.01 ), although the value for sodium citrate was not significantly different from the control (unless the cells were cultured with sodium oleate).

Finally, the relationship between the triglyceride accumulation and TNF $\alpha$ expression was analyzed by calculating the correlation coefficient for the covariance. Figure 6 shows the covariance between the two factors as determined by using the average values in Figures $\mathbf{4}$ and 5. The correlation coefficient (r) was 0.63 , and the value was increased to 0.87 when the values for sodium citrate were excluded. Therefore, there was a positive correlation between these two factors.

\section{DISCUSSION}

The current study had two objectives: to isolate a novel adipocyte cell line and clarify the differences in the native characteristics between adipocytes and preadipocytes, and to use the new-isolated adipocytes to screen for compounds that can affect the triglyceride and $\mathrm{TNF} \alpha$ levels in the cells.

Under the first objective, we isolated a novel adipocyte cell line by using the 3T3-L1 mouse preadipocytes.

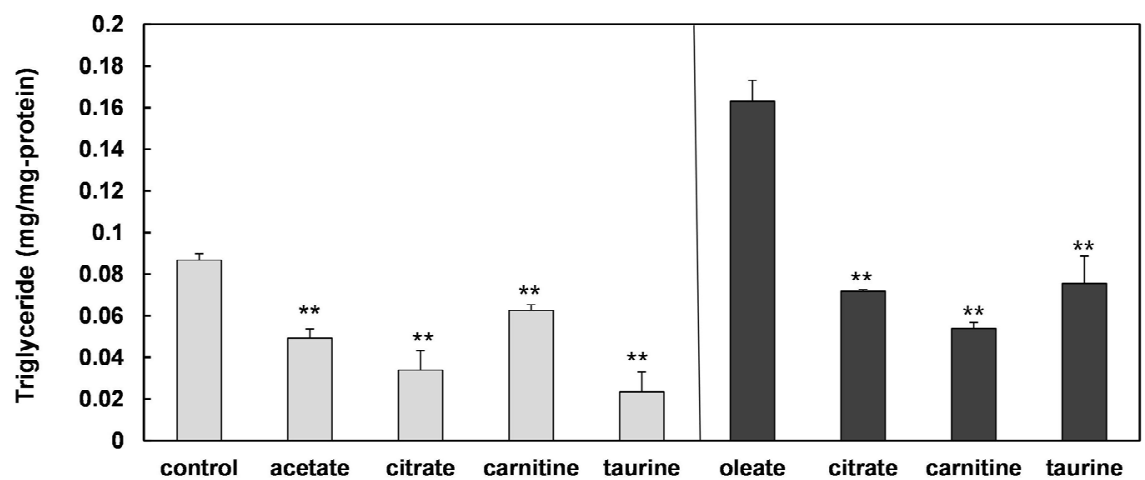

(a)

(b)

Figure 4. The effects of sodium carboxylates, carnitine and taurine on the triglyceride level in 3T3-L24 cells. The 3T3-L24 cells were cultured in the basic media without additional factors (a) or with $0.28 \mathrm{mM}$ sodium oleate; (b) A total of $0.5 \mathrm{mM}$ of sodium acetate, sodium citrate, carnitine and taurine were respectively added in these media to examine their effects. The cells cultured in the media in (a) and (b) were used as control. Bars, means \pm S.E. of 3 independent experiments. ${ }^{*} \mathrm{p}<0.05$ vs. control (without addition) and $* * \mathrm{p}<0.01$. 


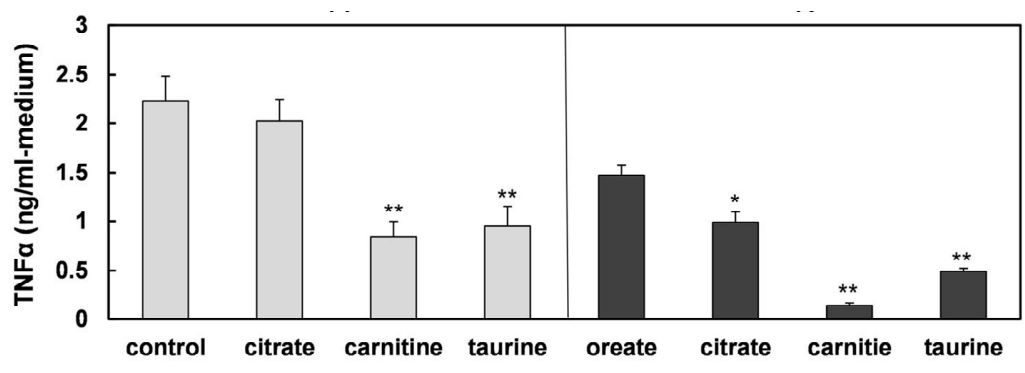

(a)

(b)

Figure 5. The effects of sodium carboxylates, carnitine and taurine on the TNF $\alpha$ secretion by adipocytes. The 3T3-L24 cells were cultured under the same conditions as in Figure 4. Bars, means \pm S.E. of 3 independent experiments. ${ }^{* * p}<$ 0.05 and $* p<0.01$ vs. control (without addition).

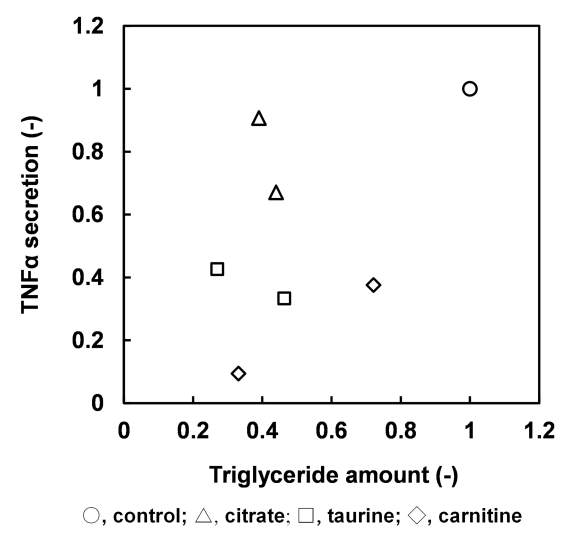

Figure 6. The relationship between the triglyceride level and TNF $\alpha$ secretion in the 3T3-L24 adipocytes. The average values of triglycerides and TNF $\alpha$ secretion in Figures $\mathbf{4}$ and $\mathbf{5}$ were divided by these control values for normalization (control: 1).

It is generally thought that the ratio of adipocytes to preadipocytes is very high in obese subjects in compareson with normal-weight subjects. Therefore, a source of adipocytes is needed to better understand metabolic syndrome. Many researchers [2-3] have used the preadipocyte 3T3-L1 cells as a useful model for adipocytes, because they can be easily differentiated to 3T3-L2 adipocyte-like cells by the addition of induction compounds, such as dexamethasone, IBMX and a PPAR $\gamma$ antagonist [15]. However, as shown in Figure 2(a), the differentiated 3T3-L2 cells did not show the full characteristics of adipocyte, because the cells not only still contained many undifferentiated 3T3-L1 preadipocytes, but also had a low ratio of adipocytes to preadipocytes, and the ratio was not constant. Indeed, the newly-isolated 3T3-L24 cells, which were screened in this study, contained few preadipocytes, making them a more appropriate model for detailed in vitro research on adipocytes.

We compared the genetic and biochemical character- istics between the 3T3-L24 and parental 3T3-L1 cells. In the genetic analysis, the expression of the $\mathrm{AP} 2, \mathrm{C} / \mathrm{EBP} \alpha$, $\mathrm{C} / \mathrm{EBP} \beta$ and PPAR $\gamma$ genes were examined. These genes were previously suggested to play important roles in the differentiation of preadipocytes to adipocytes [16-19], and the genes were not expressed or only weekly expressed in the 3T3-L1 preadipocytes as determined using a RT-PCR method [14]. As shown in Figure 2(b), all genes were highly expressed in the 3T3-L24 cells in the present study, and the expression was maintained in the absence of IBMX and other factors. Further, in a biochemical examination, 3T3-L24 adipocytes showed a higher capacity for triglyceride production than the 3T3-L1 preadipocytes, as shown in Figure 3(a). These results are in agreement with the reports that obese individuals have a high ratio of adipocytes to preadipocytes and have gained a predisposition toward obesity [20].

Under the second objective, we screened various compounds for the ability to affect triglyceride production and TNF $\alpha$ secretion. Hypertrophic WAT in an obese subject causes inflammation, aging and obliteration of the bloodflow, and finally leads to the secretion of an undesirable amount of adipocytokines. Therefore, the inhibition of hypertrophy and adipocytokine secretion would be helpful to prevent the development of (or treat existing) metabolic syndrome.

First, we examined the effects of glycerol and longchain fatty acids, the components of triglycerides. As shown in Figure 3(a), the triglyceride levels were enhanced upon the addition of long chain fatty acids, but were not enhanced by the addition of glycerol. Interestingly, the amount of triglyceride in response to the addition of sodium oleate was lower than that in response to the addition of oleic acid. These results suggest the following: there is already a sufficient amount of glycerol in cells to synthesize triglyceride by lipoprotein lipase, but long chain fatty acids are a limiting factor. The synthesis rate by lipoprotein lipase is a rate-limiting reaction when fatty acids are added to the culture, and the car- 
boxyl group is the key factor involved in the synthesis. Therefore, this suggests that some carboxylates might act as a competitor of fatty acids in the reaction of lipoprotein lipase, and a decrease in fatty acids by degradation might decrease the triglyceride level.

To address these possibilities, the effects of some carboxylates were examined in the 3T3-L24 adipocytes which were cultured in medium with or without sodium oleate. As shown in Figure 4, the addition of a carboxylate, such as sodium acetate or citrate, inhibited the triglyceride accumulation. Further, we examined the effects of addition of carnitine and taurine. Carnitine facilitates the transport of a fatty acid to an inner membrane of the mitochondria, and taurine consumes the acetyl CoA degraded from a fatty acid to synthesize cholesterol. These molecules are generally used as dietary supplements and were previously pointed out to have a relationship with metabolic syndrome [21-23]. In adipocytes cultured in media containing additional carnitine or taurine, triglyceride accumulation was inhibited (Figure 4(a)). Therefore, the enhancement of the degradation of fatty acid metabolism is also effective to decrease the triglyceride accumulation.

Finally, we also examined whether the expression of adipocytokines could be decreased by a decrease in triglyceride accumulation. TNF $\alpha$, one of the main factors involved in type 2 diabetes [9], was the focus of this study. As shown in Figures 3(b), the amount of TNF $\alpha$ produced and secreted by the adipocyte was much higher than the levels of the preadipocytes. In fact, TNF $\alpha$ was produced only in the adipocytes. This result suggests that the enhancement of TNF $\alpha$ in an obese subject might be caused by the increase in the ratio of adipocytes to preadipocytes.

We also examined whether sodium citrate, carnitine and taurine could decrease the TNF $\alpha$ secretion by 3T3L24 adipocytes under the same conditions. As shown in Figure 5, TNF $\alpha$ secretion (as well as triglyceride accumulation) could be decreased by the addition of sodium citrate, carnitine and taurine. The levels were especially decreased following the addition of carnitine or taurine. Further, the relationship between triglyceride accumulation and TNF $\alpha$ secretion in the adipocytes was analyzed (Figure 6), and the results suggested that the amount of triglyceride was related to the secretion of $\mathrm{TNF} \alpha$, because the correlation factor was high (0.87) when cells were treated with carnitine or taurine.

Obese individuals have increased concentrations of free fatty acids in their blood, which likely affects the development and progression of metabolic syndrome $[24,25]$. As shown in Figures 4(b) and 5(b), we examined the effects of free fatty acids by using sodium oleate as a model compound. Although it was reported that fatty acids regulate the production of TNF $\alpha$ and IL-10 in 3T3-L1 cells [26], the addition of sodium oleate affected led to an increase in triglyceride accumulation but no significant change in TNF $\alpha$ secretion. However, as shown in Figures 4(b) and 5(b), even in cells cultured with sodium oleate, the triglyceride accumulation and TNFa secretion could be inhibited by the addition of sodium citrate, carnitine and taurine. These results suggest that obese patients might be able to decrease the level of triglycerides in the WAT and the serum TNF $\alpha$ level by increasing their intake of carboxylates, including carnitine and/or taurine. However, obese subjects have increase not only in free fatty acids, but also in insulin, cholesterol and other adipocytokines. We did not examine the effects of all of these using the 3T3-24 adipocytes. Further studies are currently underway, and the results will be described in a subsequent manuscript.

\section{ACKNOWLEDGEMENTS}

Our group greatly thanks Ms. S. Aida, A. Fujiwara, K. Imanaka, Y. Kanda, S. Nakayama, H. Shiotsu, A. Sogo, M. Tanaka, Y. Tanaka, M. Yamashita and S. Sunami for their assistance with our research. This work was supported by grant-in aids from the School of Human Sciences and the laboratory at Kobe College.

\section{REFERENCES}

[1] Egusa, G., Murakami, F., Ito, C., Matsumoto, Y., Kado, S., Okamura, M., Mori, H., Yamane, K., Hara, H. and Yamakido, M. (1993) Westernized food habits and concentrations of serum lipids in the Japanese. Atherosclerosis, 100, 249-255. doi:10.1016/0021-9150(93)90211-C

[2] Ahima, R.S. (2006) Adipose tissue as an endocrine organ. Obesity, 14, 242-249. doi:10.1038/oby.2006.317

[3] Rosen, E.D. and Spiegelman, B.M. (2000) Molecular regulation of adipogenesis. Annual Review of Cell Biol$o g y$, 16, 145- 171. doi:10.1146/annurev.cellbio.16.1.145

[4] Matuzawa, Y. (2006) The metabolic syndrome and adipocytokines. FEBS Letters, 580, 2917-292. doi:10.1016/i.febslet.206.04.028

[5] Maeda, K., Okubo, K., Shimomura, I., Funahashi T. and Matsuzawa, K. (1996) cDNA cloning and expression of novel adipose specific collagen-like factor apM1. Biochemical and Biophysical Research Communications, 221, 286-289. doi:10.1006/bbrc.1996.0587

[6] Szkudelski, T. (2006) Intercellular mediators in regulation of leptin secretion from adipocytes. Physiological Research, 56, 503-512.

[7] Hotamisligi, G.S., Peraldi, P., Budavari, A., Ellis, R., White, M.F. and Spiegelman, B.M. (1996) IRS-1-mediated inhibition of insulin receptor tyrosine kinase activity in TNF-alpha- and obesity induced insulin resistance. Science, 271, 665-668.

doi:10.1126/science. 271.5249 .665

[8] Yamaguchi, T., Kamo, J., Waki, H., Terauchi, Y., Kubota, N., Hara, K., Mori, Y., Ide, T., Murakami, K., TsuboyamaKasaoka, N., Ezaki, O., Akanuma, Y., Gavrilova, O., Vinson, C., Reitman, M.L., Kagechika, H., Shudo, K., 
Yoda, M., Nakano, Y., Tobe, K., Nagai, R., Kimura, S., Tomita, M., Froguel, P. and Kadowaki, T. (2001) The fatderived hormone adiponectin reverses insulin resistance associated with both lipoatrophy and obesity, Nature Medicine, 7, 941-946. doi:10.1038/090984

[9] Simomura, I., Hammer, R.E., Ikemoto, S., Brown, M.S. and Gorldstein, J.L. (1999) Leptin reverses insulin resistance and diabetes mellitus in mice with congenital lipodystrophy. Nature, 401, 73-76. doi:10.1038/43448

[10] Hotamisligil, G.S., Sharg, N.S. and Spiegelman, B.M. (1993) Adipose expression of tumor necrosis factor- $\alpha$ : Direct role in obesity-linked insulin resistance. Science, 259, 87-91. doi:10.1126/science.7678183

[11] Bastard, J.P., Maachi, M., Lagathu, C., Kim, M.J., Caron, M., Vidal, H., Capeau, J. and Feve, B. (2006) Recent advances in the relationship between obesity, inflammation, and insulin resistance. European Cytokine Network, 17, 4-12.

[12] Minamimoto, T., Orimo, M., Shimizu, I., Kunieda, T., Yokoyama, M., Ito, T., Nojima, A., Nabetani, A., Oike, Y., Matsubara, H., Ishikawa, F. and Komuro, I. (2009) A crucial role for adipose tissue p53 in the regulation of insulin resistance. Nature Medicine, 15, 1082-1087. doi:10.1038/nm.2014

[13] Green, H. and Kehinde, O. (1975) An established preadipose cell line and its differentiation in culture. II. Factors affecting the adipose conversion. Cell, 5, 19-27. doi:10.1016/0092-8674(75)90087-2

[14] Gregoire, F.M., Smas, C.M. and Sul, H.S. (1998) Understanding adipocyte differentiation. Physiologcal Review 78, 783-809.

[15] Mimura, M., Nabeshima, R., Maeda, M. and Shiomi, N. (2008) A highly sensitive enzyme-linked immunosorbent assay for quantification of adipocytokines secreted by mouse adipocytes. Biochemical Engineering Journal, 43, 58-63. doi:10.1016/i.bej.2008.08.008

[16] Tang, Q.Q. and Lane, M.D. (2000) Role of C/EBP homologous protein (CHOP-10) in the programmed activation of CCAAT/enhancer binding protein- $\beta$ during adipogenesis. Proceeding of National Academy of Science in USA, 97, 12446-12450. doi:10.1073/pnas.220425597

[17] Noon, L.A., Clark, A.K. and King, P.J. (2004) A peroxisome proliferatore-response element in the murine $\mathrm{mc} 2-\gamma$ promoter regulates its transcriptional activation during differentiation of 3T3-L1 adipocytes. Journal of
Biological Chemistry, 279, 22803-22808. doi:10.1074/jbc.M401861200

[18] Prusty, D., Park, B.H., Davis, K.E. and Farmer, S.R. (2002) Activation of MEK/ERK signaling promotes adipogenesis by enhancing peroxisome proliferation-activated receptor $\gamma(\mathrm{PPAR} \gamma)$ and $\mathrm{C} / \mathrm{EBP} \alpha$ gene expression during the differentiation of 3T3-L1 preadipocytes. Journal of Biological Chemistry, 277, 46226-46232. doi:10.1074/jbc.M207776200

[19] Wu, Z., Rosen, E.D., Brun, R., Hauser, S., Adelmat, G., Troy, A.E., Mckeon, C., Darlington, G.J. and Spiegelman, B.M. (1999) Cross-regulation of C/EBP alpha and PPAR $\gamma$ controls the transcriptional pathways of adipogenesis and insulin sensitivity. Molecular Cell, 3, 151-158. doi:10.1016/S1097-2765(00)80306-8

[20] Ruderman, N., Chisholm, D., Pi-Sunyer, X. and Schneider, S. (1998) The metabolically obese, normal-weight individual revisited. Diabetes, 47, 699-713. doi:10.2337/diabetes.47.5.699

[21] Ishikawa, M., Arai, S., Takano, M., Hamada, A., Kunimasa, K. and Mon, M. (2010) Taurin's health influence on Japanese school girls. Journal of Biomedical Science, 17, S47. doi:10.1186/1423-0127-17-S1-S47

[22] Kim, H.M., Do, C.H. and Lee, D.H. (2010) Characterization of taurine as anti-obesity agent in C. elegans. Journal of Biomedical Science, 17, S33. doi:10.1186/1423-0127-17-S1-S33

[23] Derosa, G., Maffioli, P., Ferrari, I., D’Angelo, A., Fogari, E., Palumbo, I., Randazzo, S. and Cicero, A.F. (2011) Orlistat and L-carnitine compared to orlistat alone on insulin resistance in obese diabetic patients. Endocrine Journal, 57, 777-786. doi:10.1507/emdocrj.K10E-049

[24] Warensjö, E., Sundström, J., Lind, L. and Vessby, B. (2006) Factor analysis of fatty acids in serum lipids as a measure of dietary fat quality in relation to the metabolic syndrome in men. American Journal of Clinical Nutrition, 84, 442-448.

[25] Warensjö, E., Risèrus, U. and Vessby, B. (2005) Fatty acid composition of serum lipids predicts the development of the metabolic syndrome in men. Diabetologia, 48, 1999-2005. doi:10.1007/s00125-005-1897-x

[26] Badley, R.L., Fisher, F.M. and Maratos-Fisher, E. (2008) Dietary acids differentially regulate production of TNFalpha and IL-10 by murine 3T3-L1 adipocytes. Obesity, 16, 938-944. doi:10.1038/oby.2008.39 